\title{
Accounting
}

homepage: www.GrowingScience.com/ac/ac.html

\section{An integrated model of financial well-being: The role of financial behavior}

\section{Rr. Iramani ${ }^{\mathrm{a}}$ and Lutfi Lutfi ${ }^{\mathrm{a}}$}

${ }^{a}$ STIE Perbanas Surabaya, Indonesia

\begin{tabular}{l}
\hline C H R O N I C L E \\
\hline Article history: \\
Received: October 27, 2020 \\
Received in revised format: \\
November 262020 \\
Accepted: December 9, 2020 \\
Available online: \\
December 9, 2020 \\
\hline Keywords: \\
Financial behavior \\
Financial well-being \\
Indonesian household behavior
\end{tabular}

\section{Introduction}

The issue of financial well-being is very important. Success in increasing financial well-being can mean success in reducing poverty levels. This study of financial welfare is increasingly important for developing countries, such as Indonesia, which are struggling to reduce poverty levels. The World Bank report shows that as many as 25.9 million or 9.8 percent of the Indonesian population is still below the poverty line in 2018 , a slight decrease compared to the figure in 2017 , which was 10.6 percent. If this percentage of the poverty level is added to the percentage of the population which is vulnerable to returning to poverty, the number will increase sharply to 73.9 million people or around 30 percent of the total population of Indonesia (World Bank, 2019). Financial well-being is a condition where a person can meet the needs of life now and in the future, feel safe with the future, enjoy life, and cope with unexpected needs in the future (Prendergast et al., 2018). Thus, increasing financial prosperity means poverty alleviation and affects various aspects of human life. Financial well-being could affect a person's health and psychological condition (Arber et al., 2014; Shim et al., 2009). Problems in financial well-being could exacerbate social relationships and emotional distress (Kim et al., 2003) and his life satisfaction (Shim et al., 2009). Several studies have developed models of financial well-being. Porter and Garman (1993) are the first researchers to test a conceptual model of financial well-being. They examined the effect of demographic factors (gender, ethnicity, education, and employment status), objective attributes (income and number of family dependents), perceived attributes (income and wealth), and evaluated attributes (past financial experience and future financial expectations) of financial well-being. They prove that the demographic factor index, objective attributes, perceived attributes, and attributes evaluated affect financial well-being. Sabri et al. (2012) build a model of financial well-being with an emphasis on financial literacy's mediating role. They show that saving habits, financial socialization agents through parents and religion, and financial literacy affect financial well-being. Gerrans et al. (2014) develop a structural model of financial health and its relationship

* Corresponding author.

E-mail address: lutfi@perbanas.ac.id (L. Lutfi) 
to financial well-being focusing on financial literacy. They found that financial health is determined by financial satisfaction, financial status, financial behavior, financial attitude, and financial knowledge.

The previous research does not examine comprehensively the various factors that determine financial well-being. Financial wellbeing is a multidimensional concept combining financial satisfaction, the financial situation's objective status, financial attitudes, and behavior that cannot be assessed by one measure. Brüggen et al. (2017) reveal that financial well-being is influenced by financial behavior, and this behavior is influenced by various financial interventions, such as financial education. Brüggen et al. (2017) also state that financial behavior and financial health are influenced by financial knowledge and skills (Joo \& Grable, 2004; Shim et al., 2009; Xiao et al., 2014). Financial well-being is also influenced by financial status (Xiao et al., 2009) and financial experience (Davis \& Helmick, 1985). On the other hand, financial well-being is influenced by financial behavior (Joo \& Grable, 2004; Shim et al., 2009; Xiao et al., 2009). Financial behavior cannot be separated from self-control (Ainia \& Lutfi, 2019; Ajzen, 1991; Xiao et al., 2011). Perry and Morris (2005) reveal that perceptions of self-control influence financial behavior. Thus, financial behavior mediates the effect of these various variables on financial well-being (Gutter \& Copur, 2011). Financial behavior and financial health are also influenced by demographic factors, such as marital status and number of family dependents (Brüggen et al., 2017; Gutter \& Copur, 2011; Joo \& Grable, 2004; Porter \& Garman, 1993). However, these demographic factors' role may be more on strengthening or weakening the influence of various determinants of financial well-being. Good financial knowledge and experience will not be reflected in good financial well-being when family income is not sufficient to meet the necessities of life because of the large number of family dependents (Baek \& DeVaney, 2004; Joo \& Grable, 2004). Conversely, being married could encourage someone to have more responsible financial behavior because of a sense of responsibility to the family. This sense of responsibility encourages him to manage finances better to improve the family's financial welfare (Headey \& Wooden, 2004). Thus, marital status strengthens, and the number of dependents weakens the influence of financial knowledge and financial experience on financial well-being. This study discusses the dimensions of financial well-being comprehensively by investigating the concept of financial well-being and financial behavior, which involves the role of financial literacy, financial experience, financial status, locus of control, and demographic aspects. Thus, this study's main novelty aspect is to comprehensively examine the determinants of financial well-being, based on aspects of financial status, financial knowledge, financial experience, and locus of control. Another novelty of this research is to examine the mediating role of financial behavior on the influence of these various variables on financial well-being. The last important point is the role of demographic factors, which consist of income and marital status, in moderating the influence of financial knowledge and financial status on financial well-being.

\section{Literature Review and Hypothesis Development}

\subsection{Financial Well-being Concept}

Financial well-being reflects the financial status where a person or family has sufficient resources to live a comfortable life. Financial well-being means being financially healthy, happy, and free from worries. Financial well-being can be measured using objective and subjective indicators. Some objective indicators that are generally used are income, expenditure, debt, assets, net worth, and debt ratio to income. A family is viewed as financially well-off by comparing it with the national average or median data provided by the government, such as the Central Bureau of Statistics. For example, America's median family income in 2012 was approximately \$ 51,000 per year (Ackerman et al., 2012; DeNavas-Walt et al., 2013; Porter \& Garman, 1993). For Indonesia, the average income is IDR 59.1 million per year in 2019 (Statistics, 2019). Several combined measures can also be used, such as the median or average net worth or debt-to-income ratio. If a person's financial condition is above the national average, then that person is considered financially wealthier. Debt is also a special indicator to measure financial well-being. However, it is difficult to measure financial well-being directly by the level of debt. Several indicators related to debt are used to measure financial difficulties. For example, based on researchers from the Central Bank of America, a debt installment ratio above 40 percent is considered an indicator of financial distress (Ackerman et al., 2012). Meanwhile, according to the Indonesia Financial Services Authority (OJK), the problematic installment ratio to monthly income is above 35 percent (OJK, 2016). Subjective financial wellbeing measures include financial satisfaction or satisfaction with certain financial aspects, such as income satisfaction and savings satisfaction (Xiao, 2016). Financial satisfaction plays an important role in life satisfaction. Easterlin (2006) examines the relationship between happiness and overall satisfaction for four life domains (finance, family, health, and work) and discovers that financial satisfaction contributed the most to overall happiness than other satisfaction domains. Based on data from the Gallup World Poll, the results show that financial satisfaction is the strongest predictor of life evaluation (Ng \& Diener, 2014). By controlling for debt and several demographic variables, financial satisfaction is the most important predictor of financial anxiety (Archuleta et al., 2013).

\subsection{Determinants of Financial Well-being}

Several factors have been found to influence financial health, one of which is financial experience. Financial experience shows the extent to which a person has used financial products, such as savings, deposits, credit, capital market instruments, insurance, mutual funds, and various other financial products (Hogarth \& Hilgert, 2002). A better basic financial experience increases 
financial well-being. Financial experience helps someone manage their finances better (Brilianti \& Lutfi, 2020; Lewis et al., 2008). A person with much financial experience is better able to manage his assets and income to improve his financial well-being. Someone with experience in managing money, such as managing savings, investment, and credit, has a better perception of financial well-being (Sabri et al., 2012).

\section{$\mathrm{H}_{1}$ : The higher the financial experience, the better financial well-being.}

Financial knowledge is one of the crucial aspects in determining the level of financial well-being (Perry \& Morris, 2005; Purniawati \& Lutfi, 2017). Financial knowledge is needed to manage finances well (Brilianti \& Lutfi, 2020; Mudzingiri et al., 2018; Perry \& Morris, 2005; Purniawati \& Lutfi, 2017). People with good financial knowledge tend to save more and invest more for the future (Henager \& Mauldin, 2015; Lusardi \& Mitchelli, 2007; Pangestu \& Karnadi, 2020; Van Rooij et al., 2012), and are not trapped in excessive debt that causes financial difficulties (French \& McKillop, 2016; Lusardi \& Tufano, 2015). Thus, they could use financial knowledge to improve their financial well-being (Bannier \& Schwarz, 2018; Brüggen et al., 2017; Gerrans et al., 2014). People who have better knowledge tend to have greater wealth accumulation (Behrman et al., 2012) and a better perception of financial well-being (Falahati \& Sabri, 2015).

\section{$\mathrm{H}_{2}$ : The higher the financial knowledge, the better the financial well-being.}

Understanding financial well-being cannot be separated from financial status (Hong \& Swanson, 1995). The financial status reflects the financial condition of a person or family based on the level of income, wealth, and debt they have (Gerrans et al., 2014). The amount of income is an important component in determining the financial status of a family. The higher the level of family income, the better the family's financial condition (Hsieh, 2004). This, in turn, has a positive impact on the financial welfare of the family. Conversely, debt is an obligation that must be fulfilled by the family from the income generated or the wealth they have. The bigger the debt, the bigger the installments that must be paid. Consequently, the greater the ratio of debt installments to income, the worse the family's financial welfare, or in other words, the smaller the debt ratio, the wealthier a family will be (Gerrans et al., 2014)

\section{$\mathrm{H}_{3}$ : The higher the financial status, the better the financial well-being.}

Financial well-being is also influenced by how a person views the factors that affect his or her position. A person with an internal locus of control believes that what will happen to himself and his family depends on what he has done, not on external factors or fate (Grable et al., 2009; Perry \& Morris, 2005). People with an internal locus of control will strive to improve financial wellbeing because they do not want their future to depend on others' mercy. People with good self-control will be more motivated to carry out plans and be more responsible for their actions. Consequently, they are less worried about financial problems and more satisfied with their financial condition (Strömbäck et al., 2017; Sumarwan \& Hira, 1993).

\section{$\mathrm{H}_{4}$ : The higher the internal locus of control, the better the financial well-being.}

Joo and Grable (2004) state that these variables' influence on financial satisfaction is not direct, but through financial behavior. In other words, financial behavior mediates the effect of financial status, financial knowledge, and financial status on financial wellbeing. Someone who has better financial knowledge tends to have better saving behavior (Henager \& Mauldin, 2015; Jappelli \& Padula, 2013; Joo \& Grable, 2004; Lewis et al., 2008), have better preparation of retirement funds (Bucher-Koenen \& Lusardi, 2011; Lusardi \& Mitchelli, 2007), have less debt burden (French \& McKillop, 2016; Lusardi \& Tufano, 2015), and have more accumulated wealth (Behrman et al., 2012; Van Rooij et al., 2012). This good financial behavior further increases financial wellbeing (Gutter \& Copur, 2011; Henager \& Mauldin, 2015; Joo \& Grable, 2004; Shim et al., 2009). The influence of locus of control on financial well-being can also be through financial behavior (Shim et al., 2009). According to the theory of planned behavior, the perception of self-control can affect the intention to behave, and then it is reflected in actual behavior (Ajzen, 1991). Internal locus of control encourages better financial management behavior (Ariani et al., 2016; Britt et al., 2013; Perry \& Morris, 2005). Someone with an internal locus of control tends to make up the financial budget (Lim et al., 2003), save for the future (CobbClark et al., 2016), and feel more comfortable with future financial conditions (Strömbäck et al., 2017). Problems in self-control can lead to unplanned spending (Gathergood, 2012), excessive debt (Achtziger et al., 2015), and inadequate retirement funds (Kim et al., 2016). The encouragement of internal locus of control on financial behavior will further improve financial well-being (Shim et al., 2009).

\section{$\mathrm{H}_{5}$ : Financial behavior mediates the effect of financial experience, financial knowledge, financial status, and locus of control on financial well-being.}

Marital status also has an impact on the financial well-being of the family. Married status encourages someone to manage their finances better as a form of that person's responsibility towards their family (Headey \& Wooden, 2004). This, in turn, causes a married person to have better financial well-being (Delafrooz \& Paim, 2011; Porter \& Garman, 1993; Sahi, 2013). Furthermore, the number of dependents in the family can hurt the family's financial welfare (Baek \& DeVaney, 2004). A larger number of dependents require a larger income to cover their daily needs. This causes more family dependents to owe more and have less 
liquid funds (Hong \& Swanson, 1995). Marital status and number of family dependents can also moderate financial knowledge and experience on financial well-being. A person having good financial knowledge and experience with a married status will be more motivated to meet needs and improve family welfare in the future. The combination of family status and financial knowledge can further strengthen financial satisfaction (Gerrans et al., 2014). However, when the number of family dependents increases, the cost burden must also be greater. This weakens the influence of financial knowledge and experience on financial well-being.

$\mathrm{H}_{6}$ : Marital status and number of dependents moderate the effect of financial experience on financial well-being.

$\mathrm{H}_{7}$ : Marital status and number of dependents moderate the effect of financial knowledge on financial well-being.

Fig. 1 presents the conceptual research framework. Financial well-being is a dependent variable and is the focus of this study. Financial well-being is influenced by financial knowledge, financial experience, financial status, and internal locus of control. Financial knowledge, financial experience, financial status, and internal locus of control on financial well-being can directly or indirectly affect financial behavior and financial satisfaction. Last, the demographic factor of marital status and the number of family dependents moderate the influence of financial knowledge and financial experience on financial well-being.

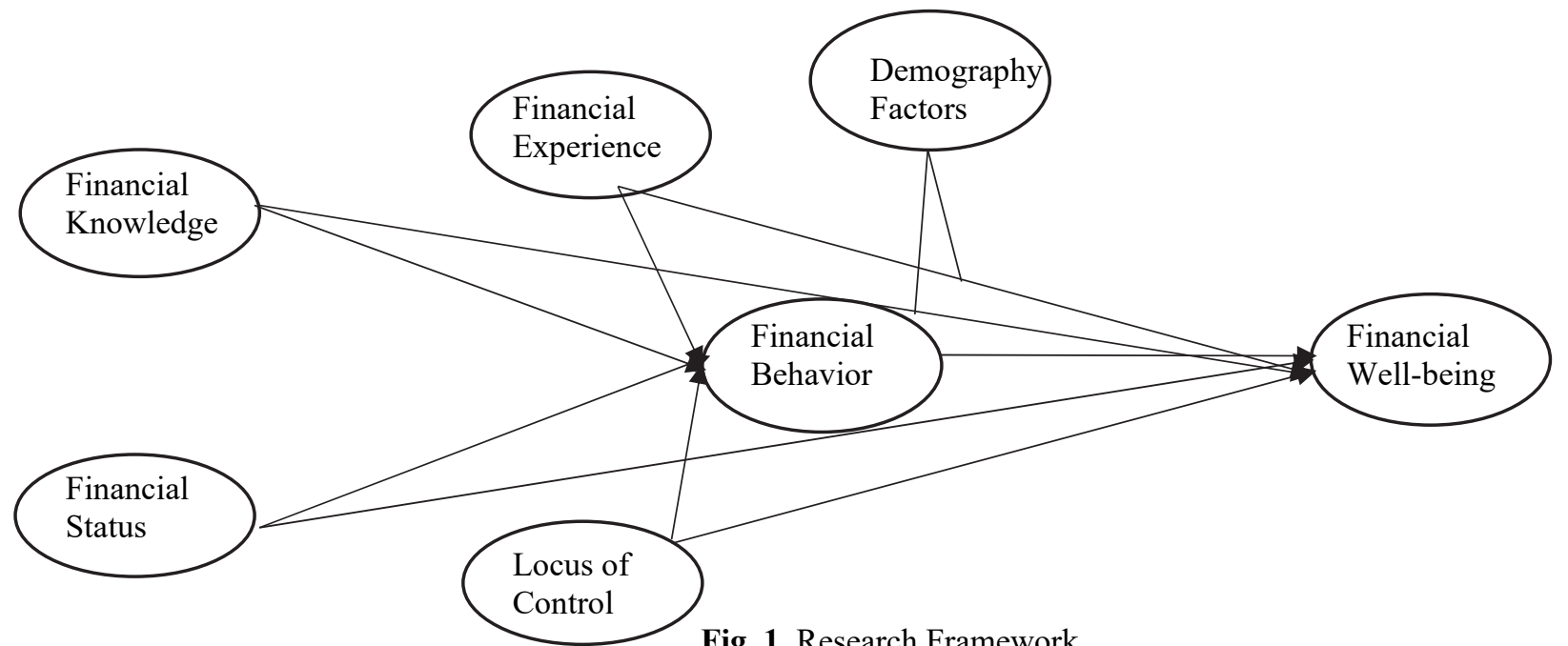

Fig. 1. Research Framework

\section{Research Methods}

\subsection{Sample \& Sampling Technique}

The sampling technique used was purposive sampling and convenience sampling. These two techniques were chosen to facilitate data collection and ensure that respondents were selected according to the research objectives. This study's respondent criteria were households residing in East Java and had a minimum monthly income of IDR 5,000,000. Minimum income is determined by considering Indonesia's per capita income, which is IDR 56 million per year. Thus, respondents in this study have an income above the national per capita income, and thus they are expected to have sufficient income to meet their basic needs and have an excess for savings or investment. Considering the COVID-19 pandemic, questionnaires are distributed online using google form. There are 10,905,696 households in East Java, and 1,284 of them participated in this study. There are 72 respondents who do not follow the sample criteria, especially concerning domicile and the minimum income. Thus, the final sample of the study is 1,158 respondents.

\subsection{Variable and Measurement}

The endogenous variable of this research is financial well-being. It is a condition where a person or family has adequate resources to live comfortably. The indicators used to measure financial well-being in this study include financial stress, financial satisfaction, financial comfort, financial worries, and financial confidence (Archuleta et al., 2013; Ng \& Diener, 2014). This variable is measured with a Likert scale of 1 to 5. The study's exogenous variables include financial knowledge, financial experience, financial status, and internal locus of control. Financial knowledge is an understanding of financial concepts that a person has as a basis for financial management. This variable's indicators include basic knowledge of finance, savings, credit, insurance, and investment (Brilianti \& Lutfi, 2020; Hilgert et al., 2003; Huston, 2010). The measurement of this variable is based on the ratio of correct answers to the total questions. Financial experience relates to the extent to which a person has or uses financial products (Brilianti \& Lutfi, 2020; Hilgert et al., 2003). The financial experience variable indicator includes banking products, pension fund products, insurance products, and investment products. Financial status is related to a person's financial condition from an income and wealth perspective (Gerrans et al., 2014). Locus of control is a person's perspective and control of an event that happens to him. 
This study uses internal locus of control, namely, self-control that comes from within the respondent. The indicators include controlling spending, solving financial problems, and implementing savings and investment (Ariani et al., 2016; Grable et al., 2009). The data scale used is an interval scale with a Likert scale ranging from "1" for "never" to " 5 " for "always." The mediating variable of is financial behavior. It is a person's behavior in managing and controlling their finances. This variable's indicators include bill payments, provision of funds for savings and investments periodically, financial control, provision for emergency funds, provision for pension funds, and provision for insurance funds. This variable is measured using a Likert scale ranging from " 1 " for "never" to " 5 " for "always." The moderating variable is demographic factors consisting of marital status and number of dependents. Marital status is measured using a nominal data scale, namely a score of " 1 " for married, and " 0 " for unmarried. The number of dependents in the family is the number of family members excluding the respondent.

\subsection{Research Instrument}

Table 1 presents the results of the validity and reliability tests. The validity test is a measurement scale used to test whether the instruments in the study are valid or not. All indicators have a factor loading greater than 0.70 and Average Variance-Extracted (AVE) above 0.50. Therefore, the indicators used in this study are valid (Hair Jr et al., 2016). Reliability test to assess the level of consistency of the stability of a score and measurement tools. All constructs have composite reliability greater than 0.60 , and Cronbach's alpha also exceeds 0.60 . Thus, the questionnaire used in this study is reliable because it shows a good level of consistency and accuracy (Hair Jr et al., 2016).

Table 1

Measurement, Validity, and Reliability

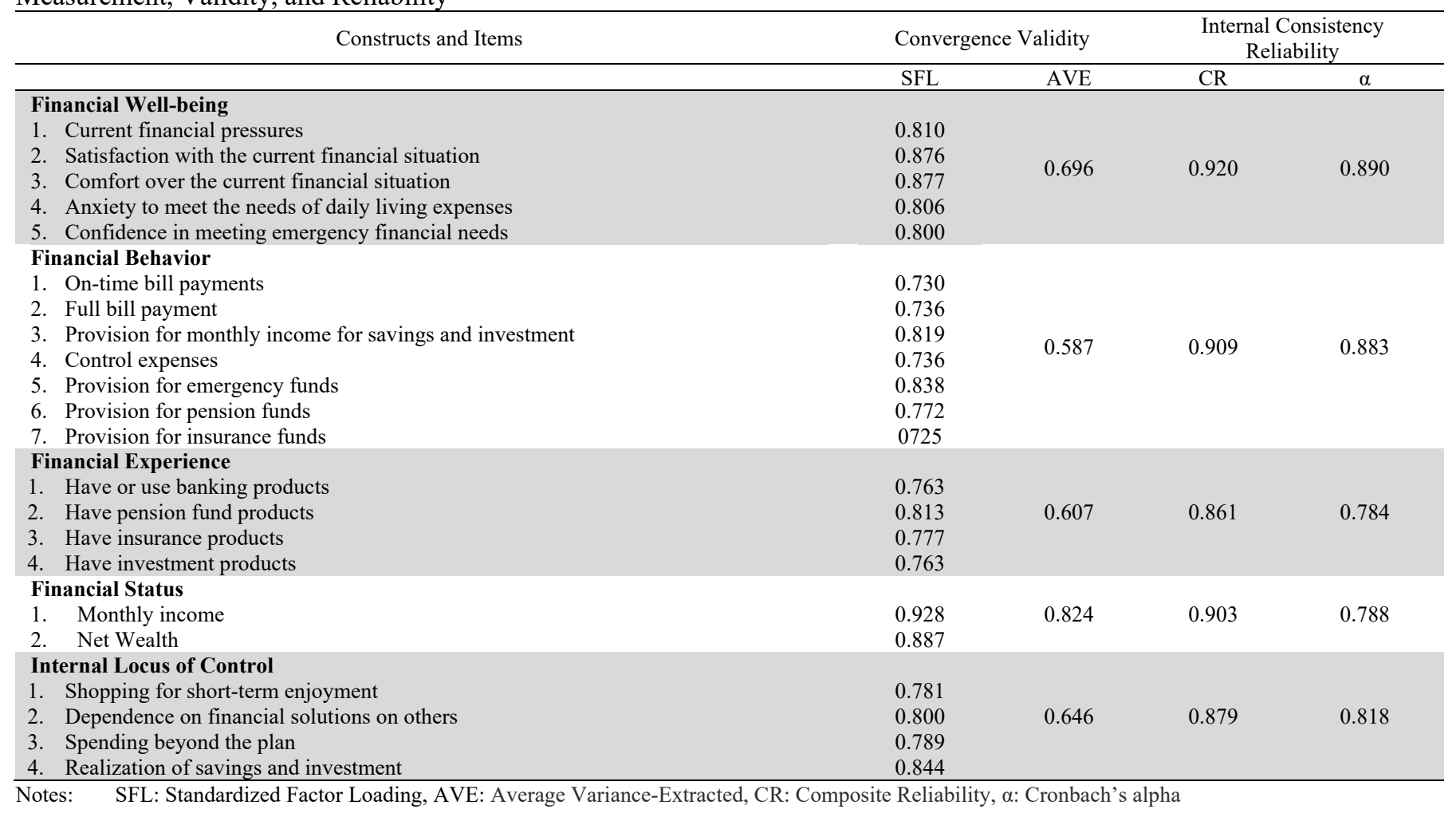

Table 2

Discriminant Validity

\begin{tabular}{lcccccccccc}
\hline \multicolumn{1}{c}{ Constructs } & \multicolumn{2}{c}{ FW } & \multicolumn{2}{c}{ FB } & \multicolumn{2}{c}{ FE } & \multicolumn{2}{c}{ FS } \\
\cline { 2 - 10 } & FLC & HTMT & FLC & HTMT & FLC & HTMT & FLC & HTMT & FLC & HTMT \\
\hline Financial Well-being & $\mathbf{0 . 8 3 4}$ & & 0.592 & 0.658 & 0.492 & 0.528 & 0.443 & 0.524 & 0.415 & 0.340 \\
Financial Behavior & 0.511 & 0.658 & $\mathbf{0 . 7 6 6}$ & & 0.480 & 0.564 & 0.298 & 0.356 & 0.523 & 0.607 \\
Financial Experience & 0.443 & 0.528 & 0.480 & 0.564 & $\mathbf{0 . 7 7 9}$ & & 0.421 & 0.529 & 0.415 & 0.512 \\
Financial Status & 0.443 & 0.524 & 0.298 & 0.356 & 0.421 & 0.529 & $\mathbf{0 . 9 0 8}$ & & 0.276 & 0.340 \\
Locus of Control & 0.415 & 0.481 & 0.523 & 0.607 & 0.443 & 0.512 & 0.276 & 0.340 & $\mathbf{0 . 8 0 4}$ & \\
\hline
\end{tabular}

Notes: FW: Financial Well-being, FB: Financial Behavior, FE: Financial Experience, FS: Financial Status, LC: Locus of Control, FLC: Fornell-Larcker criteria, HTMT: Heterotrait-Monotrait ratio

Furthermore, this study uses the Fornell-Larcker criteria and the Heterotrait-Monotrait ratio of correlations (HTMT) to test the discriminant validity. Table 2 shows that AVE's root is greater than the correlation between latent constructs based on the Fornell- 
Larcker criteria and the HTMT ratio is smaller than 0.85 for all constructs. Thus, each construct is unique and captures phenomena not represented by other constructs in the model (Hair Jr et al., 2016).

\section{Results and Discussion}

\subsection{Descriptive Analysis}

Table 3 summarizes the descriptive statistics and correlations between the variables. This table shows that about 67 percent of the respondents are married with an average of two dependents. The respondents' financial knowledge is generally quite good, with an average score of 62 percent. This means that, on average, the respondents can answer six out of ten questions. This level of financial knowledge is far above the results of a survey by the Indonesian Financial Services Authority, which states that Indonesian people's financial literacy is only 41 percent (OJK, 2017). However, this result is similar to Ariani et al. (2016) and Purniawati and Lutfi (2017). There are two questions about financial knowledge with very low scores, namely the use of credit cards and diversification benefits. Only 27 percent of respondents understand that credit cards can be used to withdraw cash from ATMs, and 31 percent of respondents who understand that increasing the number of assets in a portfolio could reduce risk. In general, respondents are quite wealthy, with an average score of 3.257, and good financial behavior, with an average score of 3.774 .

Table 3

Descriptive Statistics \& Variable Correlation

\begin{tabular}{|c|c|c|c|c|c|c|c|c|c|}
\hline \multirow{2}{*}{ Variables } & \multirow{2}{*}{ Mean } & \multirow{2}{*}{ SD } & \multicolumn{7}{|c|}{ Correlation } \\
\hline & & & FW & FB & $\mathrm{FE}$ & FS & $\mathrm{LC}$ & FK & SP \\
\hline Financial Well-being & 3.257 & 0.720 & & & & & & & \\
\hline Financial Behavior & 3.774 & 0.843 & 0.589 & & & & & & \\
\hline Financial Experience & 2.104 & 0.778 & 0.438 & 0.493 & & & & & \\
\hline Financial Status & 2.466 & 1.451 & 0.432 & 0.307 & 0.425 & & & & \\
\hline Locus of Control & 3.512 & 0.720 & 0.406 & 0.519 & 0.418 & 0.279 & & & \\
\hline Financial Knowledge & 61.969 & 14.442 & 0.492 & 0.518 & 0.388 & 0.390 & 0.419 & & \\
\hline Marital Status & 0.668 & 0.471 & 0.592 & 0.384 & 0.203 & 0.276 & 0.246 & 0.294 & \\
\hline Family Dependent & 2.114 & 0.850 & 0.372 & 0.156 & 0.268 & 0.431 & 0.155 & 0.201 & 0.379 \\
\hline
\end{tabular}

The correlation between financial well-being and financial behavior is positive as expected, with a coefficient of 0.589. All the variables studied have a positive correlation with financial well-being. The correlation coefficient between the variables is still below 0.6 , indicating there is no problem with discriminant validity. This is also supported by the results of discriminant validity tests using the Fornell-Larcker criteria and the Heterotrait-Monotrait ratio of correlations (HTMT).

\subsection{Financial Well-being Model}

Table 4 presents the results of testing the financial well-being model. The basic model directly examines the effect of all exogenous variables on financial well-being. The second model uses financial behavior as a mediating variable. The last model considers marital status (SP) as a moderating variable. The number of dependents is not used as a moderating variable because the direct test results (basic model) of this variable do not significantly affect financial well-being.

Table 4

The Results of the Financial Well-being Model

\begin{tabular}{|c|c|c|c|c|c|c|}
\hline \multirow{2}{*}{ Relationship } & \multicolumn{2}{|c|}{ Basic Model (I) } & \multicolumn{2}{|c|}{ Mediation Model (II) } & \multicolumn{2}{|c|}{ Mediation and Moderation Model (III) } \\
\hline & Coefficient & Sig. & Coefficient & Sig. & Coefficient & Sig. \\
\hline $\mathrm{FE} \rightarrow \mathrm{FW}$ & 0.117 & 0.002 & 0.116 & 0.002 & 0.129 & 0.001 \\
\hline $\mathrm{FK} \rightarrow \mathrm{FW}$ & 0.118 & 0.001 & 0.120 & 0.001 & 0.119 & 0.001 \\
\hline $\mathrm{FS} \rightarrow \mathrm{FW}$ & 0.112 & 0.004 & 0.111 & 0.005 & 0.099 & 0.018 \\
\hline $\mathrm{LC} \rightarrow \mathrm{FW}$ & 0.038 & 0.308 & 0.039 & 0.303 & 0.049 & 0.189 \\
\hline $\mathrm{MS} \rightarrow \mathrm{FW}$ & 0.482 & 0.000 & 0.485 & 0.000 & 0.484 & 0.000 \\
\hline $\mathrm{FD} \rightarrow \mathrm{FW}$ & 0.043 & 0.231 & 0.045 & 0.222 & 0.041 & 0.271 \\
\hline $\mathrm{FB} \rightarrow \mathrm{FW}$ & 0.236 & 0.000 & 0.228 & 0.000 & 0.206 & 0.000 \\
\hline $\mathrm{FE} \rightarrow \mathrm{FB}$ & & & 0.244 & 0.000 & 0.244 & 0.000 \\
\hline $\mathrm{FK} \rightarrow \mathrm{FB}$ & & & 0.291 & 0.000 & 0.291 & 0.000 \\
\hline $\mathrm{FS} \rightarrow \mathrm{FB}$ & & & 0.000 & 0.996 & 0.000 & 0.996 \\
\hline $\mathrm{LC} \rightarrow \mathrm{FB}$ & & & 0.299 & 0.000 & 0.299 & 0.000 \\
\hline $\mathrm{FE}^{*} \mathrm{MS} \rightarrow \mathrm{FW}$ & & & & & 0.060 & 0.155 \\
\hline $\mathrm{FK}^{*} \mathrm{MS} \rightarrow \mathrm{FW}$ & & & & & 0.089 & 0.005 \\
\hline R-Square & \multicolumn{2}{|c|}{0.665} & \multicolumn{2}{|c|}{0.662} & \multicolumn{2}{|c|}{0.670} \\
\hline Adjusted R-Square & \multicolumn{2}{|c|}{0.659} & \multicolumn{2}{|c|}{0.656} & \multicolumn{2}{|c|}{0.662} \\
\hline SRMR & \multicolumn{2}{|c|}{0.071} & \multicolumn{2}{|c|}{0.071} & \multicolumn{2}{|c|}{0.071} \\
\hline
\end{tabular}

Notes: FW=Financial Wellbeing; FB = Financial Behavior; FK= Financial Knowledge; FS=Financial Status; LC = Internal Locus of Control; MS = Marital Status; FD = Family Dependent 
In the basic model, all exogenous variables have a significant positive effect on financial well-being (FW), except for the internal locus of control (LC) and the number of family dependents (FD), which have insignificant effects. When financial behavior (FB) is considered as a mediating variable, this variable significantly mediates the effect of financial experience (FE), financial knowledge (FK), and internal locus of control (LC) on financial well-being. The moderation testing results of marital status indicate that this variable moderates the effect of financial knowledge on financial well-being but fails to moderate the effect of financial experience on financial well-being. The following sections discuss the test results for each research hypothesis in detail.

\subsection{The Basic Model: Direct Effect}

Table 4 shows that financial experience has a significant positive effect on financial well-being with a coefficient range of 0.117 0.129 and a significance level of 0.001-0.002 for all models. Thus, the first hypothesis of this study is accepted. Financial experience related to bank savings products, insurance products, insurance products, and capital market products helps respondents reduce financial pressure, reduce worries about fulfilling their life needs, increase financial satisfaction, improve financial comfort, and improve their ability to meet emergency needs. The results support Lewis et al. (2008), which states that financial experience helps a person manage finances well. Table 3 shows that the average score of financial experience is 2.104. In general, this is because respondents have at least one experience with financial products. Complete data on respondents' responses show that, on average, respondents own two bank savings products and one product for insurance, pension funds, or the capital market. Someone with more financial experience manages their assets and income better to improve their financial well-being (Sabri et al., 2012). Ownership of two bank deposit products helps manage their assets, where one bank savings can be used for routine needs, and the other can be used for emergency needs. Owning two bank deposits will reduce respondents' stress related to emergency expenses (such as illness, accidents) that are not predicted. Apart from owning two savings products, the respondent also owns an insurance product, a pension fund, or the capital market. This ownership increases the respondent's satisfaction with the financial situation. Respondents feel comfortable because they have enough funds to accommodate for future funding needs when retiring. This phenomenon can be explained that the higher the financial experience, the higher the financial welfare. Financial knowledge is proven to have a very significant positive effect on financial well-being, with a coefficient range of 0.118 to 0.120 and a significance level of 0.001 for the three models. This means that the second hypothesis of the study is accepted. Financial knowledge is the basic human capital that affects financial well-being. A good understanding of the concepts of inflation, interest rates, time value of money, savings, credit, insurance, and investment can encourage a person to save and invest more ((Henager \& Mauldin, 2015; Van Rooij et al., 2012) so that they wealthier (Behrman et al., 2012). Good financial knowledge also prevents excessive debt that can increase borrowing costs and the possibility of bankruptcy (French \& McKillop, 2016). Overall, good financial knowledge increases financial satisfaction and reduces the pressure to meet daily needs and emergency needs. This study supports Falahati and Sabri (2015), stating that financial knowledge increases financial well-being perceptions.

Financial status is measured using the monthly income and wealth of the respondents. The test results show that financial status has a significant positive effect on financial well-being. Thus, the third hypothesis of this study is accepted. Families who have greater monthly income and wealth have a better chance of avoiding the stress caused by difficulties in meeting the cost of living. Such families have more than sufficient funds to meet daily needs and large amounts of emergency funds, such as hospitals and children's education. In addition to a monthly income, which is more than adequate, the family also has sufficient wealth. Ownership of adequate assets makes the family feel satisfied and comfortable with its current financial condition. Thus, families with greater income and wealth feel more comfortable financially and enjoy life more (Gerrans et al., 2014). The fourth hypothesis states that an internal locus of control has a positive effect on financial well-being. The test results fail to provide evidence that internal locus of control has a significant positive effect on financial well-being. The significance level of the effect of locus of control on financial well-being is greater than 5 percent for all models. These results could indicate that locus of control does not directly affect financial well-being, but indirectly affects financial behavior (Ajzen, 1991). This study's results do not support Strömbäck et al. (2017), showing that an internal locus of control reduces financial stress and increases financial security. The difference in the results of this study may be due to differences in the measurement of financial well-being, where this study uses a composite score with a wider range of indicators that includes the ability to meet the needs of various emergency funds. The test results also provide strong evidence that marital status has a significant positive effect on financial well-being, with a coefficient range between $0.482-0.485$ for all models. Getting married makes a person have to be more responsible for his family life. This encourages the person to set aside his income and accumulate wealth for his family's benefit, both for present and future needs. As a result, this person feels more comfortable with the existing financial condition and is less worried about his ability to meet living costs for himself and his family (Gerrans et al., 2014). However, this study fails to prove that the number of dependents has a positive effect on financial well-being. Therefore, in the following discussion regarding the moderating role of demographic factors, this study only examines marital status's moderating role.

\subsection{Mediation of Financial Behavior}

Table 4 shows that financial experience, financial knowledge, and internal locus of control have a significant positive effect on financial behavior, while financial status does not significantly affect financial behavior. Furthermore, financial behavior has a 
significant positive effect on financial well-being. Thus, we could conclude that financial behavior mediates the effect of financial experience, financial knowledge, and internal locus control on financial well-being. In the case of financial experience and financial knowledge, these two variables have a significant positive direct effect on financial well-being and a significant positive indirect effect on financial well-being through financial behavior. Thus, financial behavior partially mediates this influence. Better financial knowledge encourages someone to have better saving behavior (Henager \& Mauldin, 2015; Jappelli \& Padula, 2013; Joo \& Grable, 2004; Lewis et al., 2008), to prepare better retirement funds (Bucher-Koenen \& Lusardi, 2011; Lusardi \& Mitchelli, 2007), and do not delay debt payments because this causes a high debt burden (French \& McKillop, 2016; Lusardi \& Tufano, 2015). This good financial behavior, in turn, causes the person to be wealthier (Behrman et al., 2012; Van Rooij et al., 2012). This study's results are in line with previous studies that prove that financial behavior is a mediator for financial well-being (Gutter \& Copur, 2011; Joo \& Grable, 2004). On the other hand, internal locus of control does not directly have a significant effect on financial well-being, but it has a significant indirect effect on financial well-being through financial behavior. This means that financial behavior fully mediates the influence of locus of control on financial well-being. The belief that the future depends on oneself encourages a person to have better financial behavior, such as paying bills on time, setting aside income for savings and investment, controlling expenses, and setting aside funds for pensions and insurance (Britt et al., 2013; Cobb-Clark et al., 2016; Perry \& Morris, 2005). This good financial behavior further increases perceptions of financial well-being, such as feeling comfortable with financial conditions and the ability to meet normal or emergency life needs (Shim et al., 2009). A person who is accustomed to setting aside income for savings and investment feels more comfortable because both routine and emergency needs are readily available so that the person does not feel anxious in the event of an emergency that requires large funds. Likewise, suppose someone can control expenses only for what is needed. In that case, that person will think more about setting aside funds for retirement or insurance that can cover risks that may occur in retirement and ultimately achieve financial well-being.

\subsection{Moderation of Marital Status}

An analysis of the role of moderation was carried out for marital status. The research hypothesis states that marital status strengthens the influence of financial knowledge and financial experience on financial well-being. Table 4 in the mediationmoderation model column proves that marital status strengthens the effect of financial knowledge on financial well-being, but it fails to provide sufficient evidence that marital status strengthens the effect of financial experience on financial well-being. Respondents with good financial knowledge and married status tended to be financially wealthier than those with good knowledge but were not married. This implies that married status encourages people with good financial knowledge to be more responsible for their families' financial condition (Delafrooz \& Paim, 2011; Gerrans et al., 2014; Sahi, 2013). A married person thinks about his own life and the life and survival of his wife and children. This encourages them to make more efforts related to financial management, such as saving, investing, and preparing a pension fund, increasing the comfort and security of their family's financial condition.

\section{Conclusion, Limitations, and Implications}

This study examines the financial welfare model using a sample of 1,158 households in East Java, Indonesia, analyzed using SEM_PLS. The results show that financial experience, financial knowledge, financial status, and marital status directly affect financial well-being. There is insufficient evidence that the locus and number of dependents affect financial well-being. Financial behavior significantly mediates the influence of financial behavior, financial knowledge, and locus of control on financial wellbeing. However, there is insufficient evidence that financial behavior mediates the effect of financial status on financial wellbeing. Furthermore, marital status strengthens the effect of financial knowledge on financial well-being, but it does not strengthen the effect of financial experience on financial well-being. There are two main limitations to this study. First, the sample used is households with a minimum income of Rp.5 million per month. This income figure is far above the average regional minimum wage in Indonesia in 2020, around IDR 2.7 million per month. Thus, the research results may not apply to low-income households. Future research needs to focus on examining low-income households. Second, this study uses cross-sectional data for 2020 . It does not capture the phenomenon of behavior change over time, such as during normal economic conditions and crises. Future research is expected to use longitudinal data to examine the possibility of this behavior change, especially when there is a crisis due to the COVID-19 pandemic in 2020. This study suggests that households need to improve their literacy, which is currently not good, namely with a value of 62 . The results show that financial literacy encourages better financial behavior, which in turn increases their financial welfare. Households must also be better able to control their behavior towards spending patterns and increase their savings habits to improve their financial welfare. From a regulator's perspective, the results of this study suggest that the Government and financial authorities need to improve further the effectiveness of the financial literacy and financial inclusion programs that are currently being implemented because of the level of literacy and financial inclusion of the Indonesian people is still not satisfactory. The government and financial authorities need to campaign more for frugality among the public, and especially this is very important during the current economic crisis so that people do not experience financial problems.

\section{References}

Achtziger, A., Hubert, M., Kenning, P., Raab, G., \& Reisch, L. (2015). Debt out of control, The links between self-control, compulsive buying, and real debts. Journal of Economic Psychology, 49, 141-149. 
Ackerman, R. A., Fries, G., \& Windle, R. A. (2012). Changes in US family finances from 2007 to 2010 , Evidence from the Survey of Consumer Finances. Federal Reserve Bulletin, 100(4), 1-80.

Ainia, N. S. N. \& Lutfi, L. (2019). The influence of risk perception, risk tolerance, overconfidence, and loss aversion towards investment decision making. Journal of Economics, Business, \& Accountancy Ventura, 21(3), 401-413.

Ajzen, I. (1991). The theory of planned behavior. Organizational behavior and human decision processes, 50(2), $179-211$.

Arber, S., Fenn, K., \& Meadows, R. (2014). Subjective financial well-being, income and health inequalities in mid and later life in Britain. Social Science \& Medicine, 100, 12-20.

Archuleta, K. L., Dale, A., \& Spann, S. M. (2013). College Students and Financial Distress, Exploring Debt, Financial Satisfaction, and Financial Anxiety. Journal of Financial Counseling and Planning, 24(2), 50-62.

Ariani, S., Rahmah, P. A. A. A., Putri, Y. R., Rohmah, M., Budiningrum, A., \& Lutfi, L. (2016). Pengaruh literasi keuangan, locus of control, dan etnis terhadap pengambilan keputusan investasi. Journal of Business and Banking, 5(2), 257-270.

Baek, E. \& DeVaney, S. A. (2004). Assessing the baby boomers' financial wellness using financial ratios and a subjective measure. Family and Consumer Sciences Research Journal, 32(4), 321-348.

Bannier, C. E. \& Schwarz, M. (2018). Gender-and education-related effects of financial literacy and confidence on financial wealth. Journal of Economic Psychology, 67, 66-86.

Behrman, J. R., Mitchell, O. S., Soo, C. K., \& Bravo, D. (2012). How financial literacy affects household wealth accumulation. American Economic Review, 102(3), 300-304.

Brilianti, T. R. \& Lutfi, L. (2020). Pengaruh pendapatan, pengalaman keuangan dan pengetahuan keuangan terhadap perilaku keuangan keluarga di kota Madiun. Journal of Business and Banking, 9(2).

Britt, S., Cumbie, J., \& Bell, M. (2013). The influence of locus of control on student financial behavior. College Student Journal, 47(1), 178-184.

Brüggen, E. C., Hogreve, J., Holmlund, M., Kabadayi, S., \& Löfgren, M. (2017). Financial well-being, A conceptualization and research agenda. Journal of Business Research, 79, 228-237. doi,https,//doi.org/10.1016/j.jbusres.2017.03.013

Bucher-Koenen, T. \& Lusardi, A. (2011). Financial literacy and retirement planning in Germany. Journal of Pension Economics \& Finance, 10(4), 565-584.

Cobb-Clark, D. A., Kassenboehmer, S. C., \& Sinning, M. G. (2016). Locus of control and savings. Journal of Banking \& Finance, 73, 113-130.

Davis, E. P. \& Helmick, S. A. (1985). Family financial satisfaction, The impact of reference points. Home Economics Research Journal, $14(1), 123-131$.

Delafrooz, N. \& Paim, L. H. (2011). Determinants of financial wellness among Malaysia workers. African Journal of Business Management, 5(24), 10092.

DeNavas-Walt, C., Proctor, B. D., \& Smith, J. C. (2013). Income, Poverty, and Health Insurance Coverage in the United States, 2012. Current Population Reports P60-245. US Census Burea.

Easterlin, R. A. (2006). Life cycle happiness and its sources, Intersections of psychology, economics, and demography. Journal of Economic Psychology, 27(4), 463-482.

Falahati, L. \& Sabri, M. F. (2015). An exploratory study of personal financial wellbeing determinants, Examining the moderating effect of gender. Asian Social Science, 11(4), 33.

French, D. \& McKillop, D. (2016). Financial literacy and over-indebtedness in low-income households. International Review of Financial Analysis, 48, 1-11.

Gathergood, J. (2012). Self-control, financial literacy and consumer over-indebtedness. Journal of Economic Psychology, 33(3), 590602.

Gerrans, P., Speelman, C., \& Campitelli, G. (2014). The relationship between personal financial wellness and financial wellbeing, A structural equation modelling approach. Journal of Family and Economic Issues, 35(2), 145-160.

Grable, J. E., Park, J. Y., \& Joo, S. H. (2009). Explaining financial management behavior for Koreans living in the United States. Journal of consumer affairs, 43(1), 80-107.

Gutter, M. \& Copur, Z. (2011). Financial behaviors and financial well-being of college students, Evidence from a national survey. Journal of family and economic Issues, 32(4), 699-714.

Hair Jr, J. F., Hult, G. T. M., Ringle, C., \& Sarstedt, M. (2016). A primer on partial least squares structural equation modeling (PLSSEM). In, Sage publications.

Headey, B. \& Wooden, M. (2004). The effects of wealth and income on subjective well-being and ill-being. Economic record, 80, S24S33.

Henager, R. \& Mauldin, T. (2015). Financial literacy, The relationship to saving behavior in low-to moderate-income households. Family and Consumer Sciences Research Journal, 44(1), 73-87.

Hilgert, M. A., Hogarth, J. M., \& Beverly, S. G. (2003). Household financial management, The connection between knowledge and behavior. Fed. Res. Bull., 89, 309-322.

Hogarth, J. M. \& Hilgert, M. A. (2002). Financial knowledge, experience and learning preferences, Preliminary results from a new survey on financial literacy. Consumer Interest Annual, 48(1), 1-7.

Hong, G.-S. \& Swanson, P. M. (1995). Comparison of financial well-being of older women, 1977 and 1989. Journal of Financial Counseling and Planning, 6, 129.

Hsieh, C.-M. (2004). Income and financial satisfaction among older adults in the United States. Social indicators research, 66(3), 249266. 
Huston, S. J. (2010). Measuring financial literacy. Journal of consumer affairs, 44(2), 296-316.

Jappelli, T. \& Padula, M. (2013). Investment in financial literacy and saving decisions. Journal of Banking \& Finance, 37(8), $2779-2792$.

Joo, S.-h. \& Grable, J. E. (2004). An exploratory framework of the determinants of financial satisfaction. Journal of family and economic Issues, 25(1), 25-50.

Kim, J., Garman, E. T., \& Sorhaindo, B. (2003). Relationships among credit counseling clients' financial wellbeing, financial behaviors, financial stressor events, and health. Journal of Financial Counseling and Planning, 14(2), 75-87.

Kim, K. T., Lee, J. M., \& Hong, E. (2016). The role of self-control on retirement preparedness of US households. International Journal of Human Ecology, 17(2), 31-42.

Lewis, J. K., Mimura, Y., Mauldin, T., Rupured, M., \& Jordan, J. (2008). Financial information, is it related to savings and investing knowledge and financial behavior of teenagers? Journal of Financial Counseling and Planning, 19(2).

Lim, V. K., Teo, T. S., \& Loo, G. L. (2003). Sex, financial hardship and locus of control, an empirical study of attitudes towards money among Singaporean Chinese. Personality and Individual Differences, 34(3), 411-429.

Lusardi, A. \& Mitchelli, O. S. (2007). Financial literacy and retirement preparedness, Evidence and implications for financial education. Business economics, 42(1), 35-44.

Lusardi, A. \& Tufano, P. (2015). Debt literacy, financial experiences, and overindebtedness. ournal of Pension Economics \& Finance, 14(4), 332-368.

Mudzingiri, C., Mwamba, J. W. M., \& Keyser, J. N. (2018). Financial behavior, confidence, risk preferences and financial literacy of university students. Cogent Economics \& Finance, 6(1), 1512366.

$\mathrm{Ng}$, W. \& Diener, E. (2014). What matters to the rich and the poor? Subjective well-being, financial satisfaction, and postmaterialist needs across the world. Journal of personality and social psychology, 107(2), 326.

OJK. (2016). Perencanaan Keuangan Keluarga. Jakarta, Otoritas Jasa Keuangan.

OJK. (2017). Survei Nasional Literasi dan Inklusi Keuangan 2016. Jakarta, Otoritas Jasa Keuangan.

Pangestu, S. \& Karnadi, E. B. (2020). The effects of financial literacy and materialism on the savings decision of generation Z Indonesians. Cogent Business \& Management, 7(1), 1743618.

Perry, V. G. \& Morris, M. D. (2005). Who is in control? The role of self-perception, knowledge, and income in explaining consumer financial behavior. Journal of consumer affairs, 39(2), 299-313.

Porter, N. M. \& Garman, E. T. (1993). Testing a Conceptual Model of Financial Well-Being. Journal of Financial Counseling and Planning, 4, 134-164.

Prendergast, S., Blackmore, D., Kempson, E., Russell, R., \& Kutin, J. (2018). Financial well-being, A survey of adults in Australia. In, ANZ Melbourne, Australia.

Purniawati, R. T. \& Lutfi, L. (2017). Literasi keuangan dan pengelolaan keuangan keluarga dalam perspektif budaya Jawa dan Bugis. Journal of Business and Banking, 7(1), 31-46.

Sabri, M. F., Cook, C. C., \& Gudmunson, C. G. (2012). Financial well-being of Malaysian college students. Asian Education and Development Studies, 5(1), 153-170.

Sahi, S. K. (2013). Demographic and socio-economic determinants of financial satisfaction. International Journal of Social Economics.

Shim, S., Xiao, J. J., Barber, B. L., \& Lyons, A. C. (2009). Pathways to life success, A conceptual model of financial well-being for young adults. Journal of Applied Developmental Psychology, 30(6), 708-723.

Strömbäck, C., Lind, T., Skagerlund, K., Västfjäll, D., \& Tinghög, G. (2017). Does self-control predict financial behavior and financial well-being? Journal of Behavioral and Experimental Finance, 14, 30-38.

Sumarwan, U. \& Hira, T. K. (1993). The effects of perceived locus of control and perceived income adequacy on satisfaction with financial status of rural households. Journal of Family and Economic Issues, 14(4), 343-364.

Van Rooij, M., Lusardi, A., \& Alessie, R. J. (2012). Financial literacy, retirement planning and household wealth. The Economic Journal, $122(560), 449-478$

World Bank. (2019). Indonesia Economic Quarterly, Investing in People. In Bank, W. (Series Ed.), (pp. 1-76).

Xiao, J. J. (2016). Consumer Financial Capability and Wellbeing. In Handbook of consumer finance research (pp. 3-17), Springer.

Xiao, J. J., Chen, C., \& Chen, F. (2014). Consumer financial capability and financial satisfaction. Social Indicators Research, 118(1), 415-432.

Xiao, J. J., Tang, C., Serido, J., \& Shim, S. (2011). Antecedents and consequences of risky credit behavior among college students, Application and extension of the theory of planned behavior. Journal of Public Policy \& Marketing, 30(2), $239-245$.

Xiao, J. J., Tang, C., \& Shim, S. (2009). Acting for happiness, Financial behavior and life satisfaction of college students. Social Indicators Research, 92(1), 53-68.

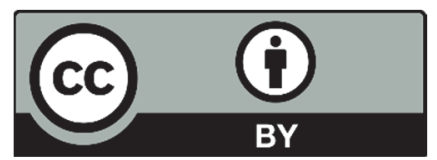

(C) 2021 by the authors; licensee Growing Science, Canada. This is an open access article distributed under the terms and conditions of the Creative Commons Attribution (CC-BY) license (http://creativecommons.org/licenses/by/4.0/). 